\title{
Immunoprotein deposition in synovial tissue in Reiter's syndrome
}

\author{
ANDREW R. BALDASSARE, TERRY D. WEISS, CHENG C. TSAI, \\ R. EUGENE ARTHUR, TERRY L. MOORE, AND JACK ZUCKNER
}

From the St Louis University School of Medicine, Division of Rheumatology, St Louis, Missouri, USA

SUMmARY The aetiology of Reiter's syndrome (RS) is unknown. In order to evaluate the role of immunological mechanisms in this disease we performed synovial biopsies on 12 patients with RS looking for deposition of immunoglobulins and complement components in synovial tissue. By immunofluorescent techniques 11 synovia were found to have immunoprotein deposition. IgM deposition was found around vessels in 8 synovia and in the interstitial tissue in 4 . $\mathrm{C} 3$ was present perivascularly in 11 cases; in 4 of those there was also staining in the interstitial tissue. No immunoproteins were found in infiltrating or synovial lining cells. The finding of immunoproteins in the synovium of the majority of patients with RS suggests that immunological mechanisms are involved in the pathogenesis of this disease.

The aetiology of Reiter's syndrome (RS) is unknown. Its relationship to sexual contact and epidemic dysentery has led investigators to see an infectious aetiology, but efforts to find a causative agent have been largely unsuccessful. Reports by Brewerton et al. ${ }^{1}$ and Morris et al. ${ }^{2}$ that $75-96 \%$ of RS patients are HLA B27 positive have spurred interest in genetic mechanisms which might play a role in its pathogenesis. A predetermined susceptibility for developing RS is likely. Immunological factors have also received consideration in the pathogenesis of RS. Other reports ${ }^{34}$ support this possibility.

In an effort better to understand immunological mechanisms in RS we have performed synovial biopsies on 12 patients with the disease looking for deposition of immunoglobulins and complement components in the involved synovium. Our findings show a consistent pattern of immunoprotein deposition implicating immune phenomena as taking part in the pathogenesis of RS.

\section{Materials and methods}

Twelve patients with RS were seen between July 1974 and March 1977 at St Louis University affiliated hospitals. History and physical examinations were performed in all cases by a member of Accepted for publication 4 June 1980

Correspondence to Andrew R. Baldassare MD, St Louis University School of Medicine, 1325 South Grand Boulevard, St Louis Missouri 63104, USA. the Division of Rheumatology. Their clinical features are shown in Table 1. Eleven of the 12 patients were males. Ages ranged from 6 to 41 years. Eleven patients had the complete triad of nonspecific urethritis, arthritis, and eye lesions. The eye findings consisted of conjunctivitis in 10 patients and iridocyclitis in 1. One patient had no ophthalmological abnormality. All had urethritis and active synovitis. The joints most frequently involved were knees (12), ankles (4), metatarsophalangeal (MTP) (2), interphalangeal (IP) of the toes (1), and the wrists (1). Other findings included circinate balanitis in 6 and painless buccal ulcerations in 2 . One patient had diarrhoea; serological and stool studies for shigella, salmonella, and yersinia organisms proved negative. Three of the patients were treated with penicillin, 2 with ampicillin, and 1 with oxacillin. One patient treated with ampicillin also received tetracycline. Results of antibiotic therapy were unsatisfactory in all 6 patients.

Laboratory testing included a complete blood count (CBC), urine analysis, erythrocyte sedimentation rate (ESR) by Westergren method, rheumatoid factor by latex fixation, fluorescent antinuclear antibody (FANA), and HLA B27 antigen. Paired determinations for complement components $(\mathrm{C} 3, \mathrm{C} 4)$ and sugar and total protein in the blood and synovial fluid were performed in 7 cases. Complement components were assayed by immunodiffusion. The values for synovial $\mathrm{C} 3$ and 
Table 1 Clinical features

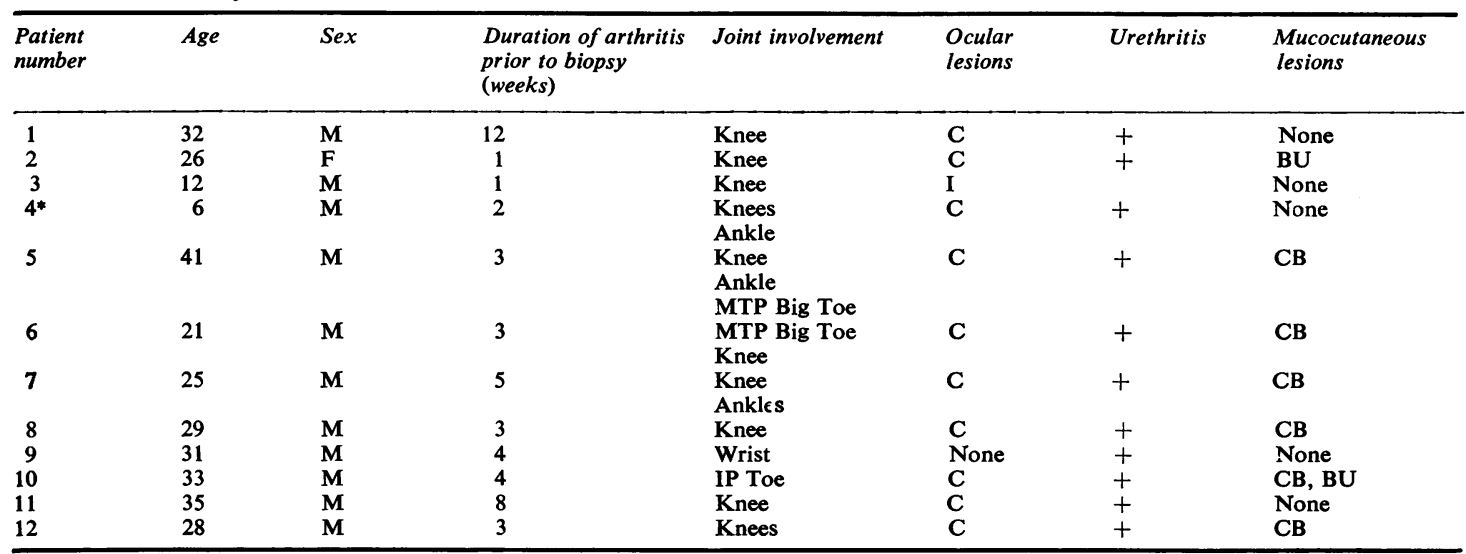

$\mathbf{C}=$ conjunctivitis. $\mathbf{I}=$ iridocyclitis. $\mathbf{B U}=$ buccal ulcerations. $\mathbf{C B}=$ circinate balanitis. $\mathbf{M T P}=$ metatarsal phalangeal joint. $\mathbf{I P}=$ interphalangeal joint. *Diarrhoea was present in this patient.

C4 were calculated by using a ratio of the complement component to protein. Other tests on synovial fluid included a white blood cell count and differential. In addition, cultures were performed on all synovial fluid samples and urethral discharges for pyogenic organisms with special culturing on warmed chocolate agar for Neisseria gonorrheae. Testing for the latter was also performed on the blood in 4 patients and on eye secretions in 3. Vaginal cultures and smears were also obtained in the 1 female patient.

Ten closed synovial biopsies of the knees were performed with a Parker-Pearson needle. Open surgical biopsies were obtained from 2 joints one of a wrist, and the other of an interphalangeal joint of a toe. The biopsies were obtained from 1 week to 4 months after the onset of arthritis. Synovial tissue was bisected; one portion was fixed in formalin and subsequently stained with haematoxylin and eosin ( $H$ and $E)$. The other portion was snap-frozen in liquid nitrogen and stored at $-70^{\circ} \mathrm{C}$. Multiple $4 \mu \mathrm{m}$ sections were cut and washed in phosphate buffered saline (PBS) and then fixed in equal amounts of ether and $95 \%$ ethanol. The tissue was then refixed in $95 \%$ ethanol and washed again twice in PBS. The sections were next stained directly with fluoresceinconjugated rabbit antiserum against human $\mathrm{IgG}$, IgM, IgA, IgE, fibrin/fibrinogen, C3, and C4 (Meloy Laboratories, Springfield, Va, and Behring Diagnostics, Sommerville, NJ). After staining, the tissue was washed twice in PBS. Intensity of fluorescence was then reported on a scale of $0-4+$. Immunoprotein localisation was designated for lining cells, infiltrating cells, connective tissue, or vessels.
Twenty other patients who underwent synovial biopsies during the time of this study were used as controls. Included were 6 patients with osteoarthritis (OA), 9 with rheumatoid arthritis (RA), and 5 with juvenile rheumatoid arthritis (JRA).

\section{Results}

Table 2 illustrates the laboratory findings in our patients. Haemoglobin varied from 11.4 to 15.5 $\mathrm{g} / \mathrm{dl}$, leucocytes were 5.6 to $19.0 \times 10^{9} / 1$, and the ESR was 22 to $90 \mathrm{~mm} / \mathrm{h}$. Six patients had pyuria. Eleven patients were HLA B27 positive, including the patient without eye findings. A 4-year-old boy with diarrhoea, urethritis, conjunctivitis, and arthritis was HLA B27 negative. Tests for rheumatoid factor and FANA were negative in all patients. Synovial fluid leucocyte counts ranged from 1.8 to $36.0 \times 10^{9} / 1$ with $75 \%$ or more polymorphonuclear leucocytes. All cultures were negative. Glucose concentrations in blood and synovial fluid were also normal.

Histological examination of the synovium revealed hypervascularity and thickening of the interstitial tissue in 11 cases. One patient had a normal synovium. The cellular inflammatory reaction was acute in 1 synovium, chronic in 6 , both acute and chronic in 4, and not present in 1. An example of acute and chronic inflammatory changes in the synovium is shown in Fig. 1.

With immunofluorescent techniques 11 synovia showed immunoprotein deposition. These findings are shown in Table 3. IgM and C3 deposits were found together in 9 cases and $\mathrm{C} 3$ alone in 2. IgM deposition was found perivascularly in 8 synovia and 
Table 2 Laboratory findings

\begin{tabular}{|c|c|c|c|c|c|c|c|c|c|c|c|c|c|c|}
\hline \multirow[b]{2}{*}{$\begin{array}{l}\text { Patient } \\
\text { number }\end{array}$} & \multicolumn{7}{|l|}{ Blood } & \multirow{2}{*}{$\frac{\text { Urine }}{\text { Micro }}$} & \multicolumn{6}{|c|}{ Synovial fluid } \\
\hline & $\begin{array}{l}H g b \\
r(g / d l)\end{array}$ & $\begin{array}{l}\text { WBC } \\
\text { cells } / \\
\mathrm{mm}^{3}\end{array}$ & $\begin{array}{l}E S R \\
(\mathrm{~mm} / \mathrm{h})\end{array}$ & $\begin{array}{l}H L A \\
B 27\end{array}$ & $\begin{array}{l}\text { Glucose } \\
\text { (mg/dl) }\end{array}$ & $\begin{array}{l}C 3^{*} \\
(m g / d l)\end{array}$ & $\begin{array}{l}C 4^{*} \\
(m g / d l)\end{array}$ & & $\begin{array}{l}W B C \\
\text { cells/ } \\
\mathrm{mm}^{3}\end{array}$ & $\begin{array}{l}\text { Polys } \\
(\%)\end{array}$ & Culture & $\begin{array}{l}\text { Glucose } \\
\text { (mg/dl) }\end{array}$ & $\begin{array}{l}\text { C3/ } \\
\text { protein }\end{array}$ & $C 41$ \\
\hline 1 & $11 \cdot 4$ & 8000 & 50 & + & 80 & - & $\bar{n}$ & Pyuria & $\bar{c}$ & $\overrightarrow{10}$ & $\bar{\pi}$ & - & - & $\overline{30}$ \\
\hline 2 & $11 \cdot 3$ & 17000 & 38 & + & 90 & 70 & 30 & Pyuria & 6500 & 95 & Negative & 70 & 175 & 30 \\
\hline 3 & $14 \cdot 2$ & 19000 & 28 & + & 125 & 228 & 27 & Pyuria & 36000 & 92 & Negative & 121 & 123 & 20 \\
\hline 4 & $11 \cdot 4$ & 10000 & 22 & Negative & 166 & 152 & 20 & Pyuria & 5000 & 21 & Negative & 58 & 15 & 9 \\
\hline 5 & $12 \cdot 3$ & 7800 & 46 & + & 123 & 200 & 20 & Negative & 5700 & 75 & Negative & 88 & 150 & 40 \\
\hline 6 & $12 \cdot 7$ & 9800 & 40 & + & 90 & 68 & 35 & Pyuria & 1800 & 80 & Negative & 80 & 58 & 43 \\
\hline 7 & $14 \cdot 0$ & 5600 & 32 & + & 90 & - & $\overline{-}$ & Negative & $\overline{70}$ & $\overline{-}$ & $\overline{0}$ & 一 & 一 & - \\
\hline 8 & $13 \cdot 0$ & 8000 & 57 & + & 100 & 91 & 28 & Negative & 7300 & 85 & Negative & - & 42 & $11 \cdot 5$ \\
\hline 9 & $13 \cdot 5$ & 90000 & 60 & + & 100 & 一 & 一 & Negative & 一 & 一 & 一 & - & 一 & - \\
\hline 10 & $14 \cdot 0$ & 7000 & 50 & + & 90 & - & $\overline{-}$ & Negative & - & - & $\vec{a}$ & 一 & - & $\overline{0}$ \\
\hline 11 & $12 \cdot 9$ & 6000 & 90 & + & 77 & 124 & 52 & Negative & 3200 & 80 & Negative & 83 & 72 & 36 \\
\hline 12 & $15 \cdot 5$ & 14000 & 90 & + & 100 & 68 & 32 & Pyuria & 8000 & 90 & Negative & 81 & 31 & 34 \\
\hline
\end{tabular}

*Normal serum level of C3 $=55-120 \mathrm{mg} / \mathrm{dl}$ and of $\mathrm{C4}=20-50 \mathrm{mg} / \mathrm{dl}$.

SI conversion: Glucose $\mathrm{mmol} / \mathrm{l}=\mathrm{mg} / \mathrm{dl} \times 0.0555$. Leucocytes $\times 10^{9} / 1=\mathrm{n} / \mathrm{mm}^{3} \times 10^{6}$.

WBC = leucocytes. Polys = polymorphonuclear leucocytes.

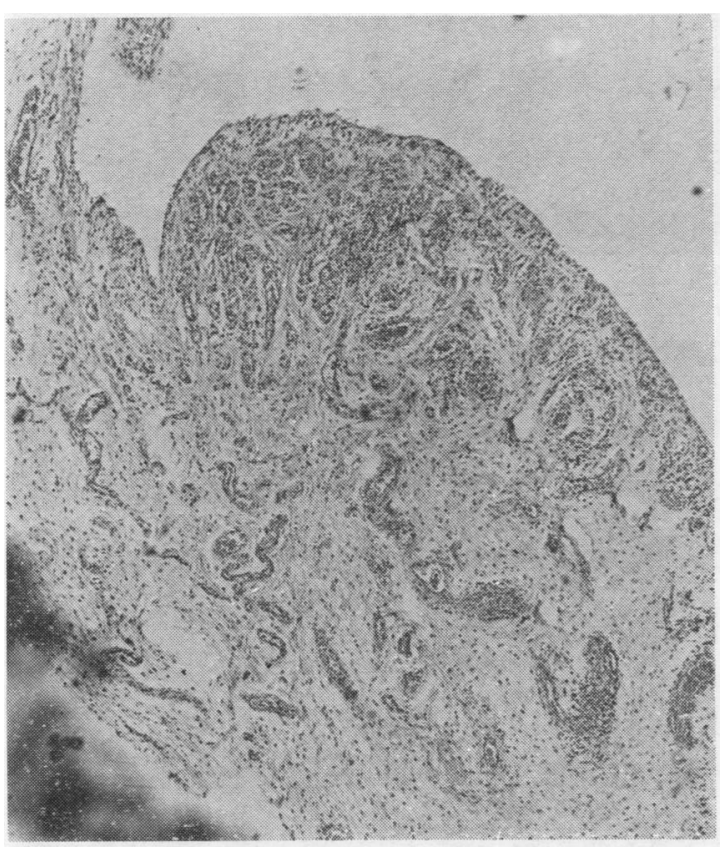

Fig. 1A. Synovium of $H$ and $E$ staining revealing hypervascularity, hyperplasia of synovial lining cells, and infiltration with mononuclear and polymorphonuclear cells $(\times 23)$.

in the interstitial tissue in 4 . C3 was present perivascularly in 11 cases; in 4 of these there was also staining of the interstitial tissue. $\mathrm{C} 4$ was not present in 4 cases tested. There was IgE deposition in 3 specimens. IgG and IgA were not detected. No immunoproteins were found in infiltrating cells or synovial lining cells. The pattern of immunoglobulin staining was finely granular in most patients, with

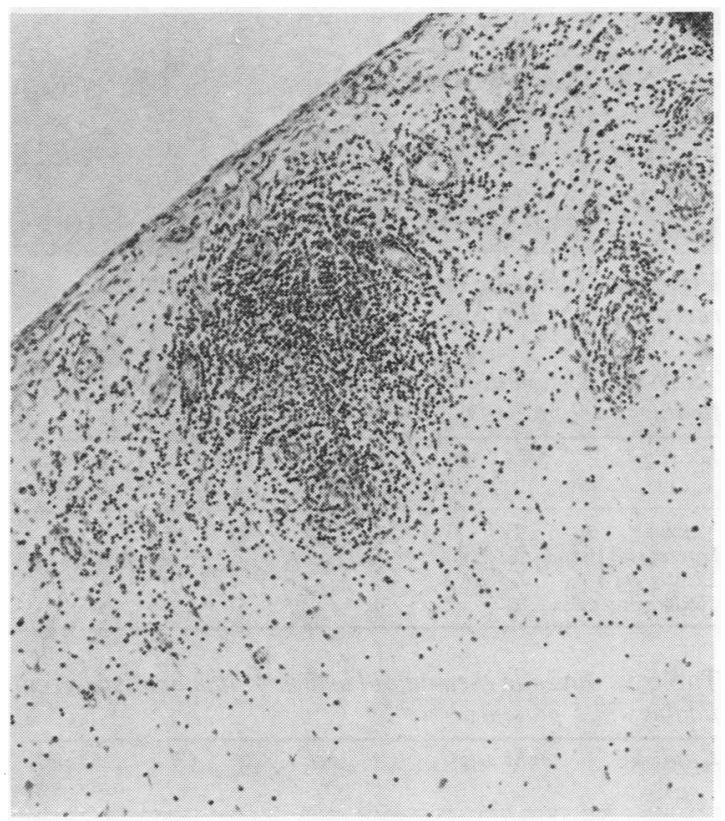

Fig. 1B. Synovium on $H$ and $E$ staining revealing predominantly lymphocytic infiltration $(\times 60)$.

Table 3 Reiter's syndrome: immunofluorescent findings in 12 patients

\begin{tabular}{|c|c|c|c|c|c|c|c|}
\hline Location & $\operatorname{Ig} M$ & $I g G$ & $\operatorname{Ig} A$ & $\operatorname{Ig} E$ & $C 3$ & $C 4$ & $\begin{array}{l}\text { Fibrin/ } \\
\text { fibrinogen }\end{array}$ \\
\hline $\begin{array}{l}\text { Vessels } \\
\text { Interstitial }\end{array}$ & 8 & 0 & 0 & 1 & 11 & $0 *$ & 8 \\
\hline tissue & 4 & 0 & 0 & 2 & 4 & $0^{*}$ & 4 \\
\hline Lining cells & 0 & 0 & 0 & 0 & 0 & 0 & 0 \\
\hline $\begin{array}{l}\text { Infiltrating } \\
\text { cells }\end{array}$ & 0 & 0 & 0 & 0 & 0 & 0 & 0 \\
\hline
\end{tabular}

*Four synovia tested. 


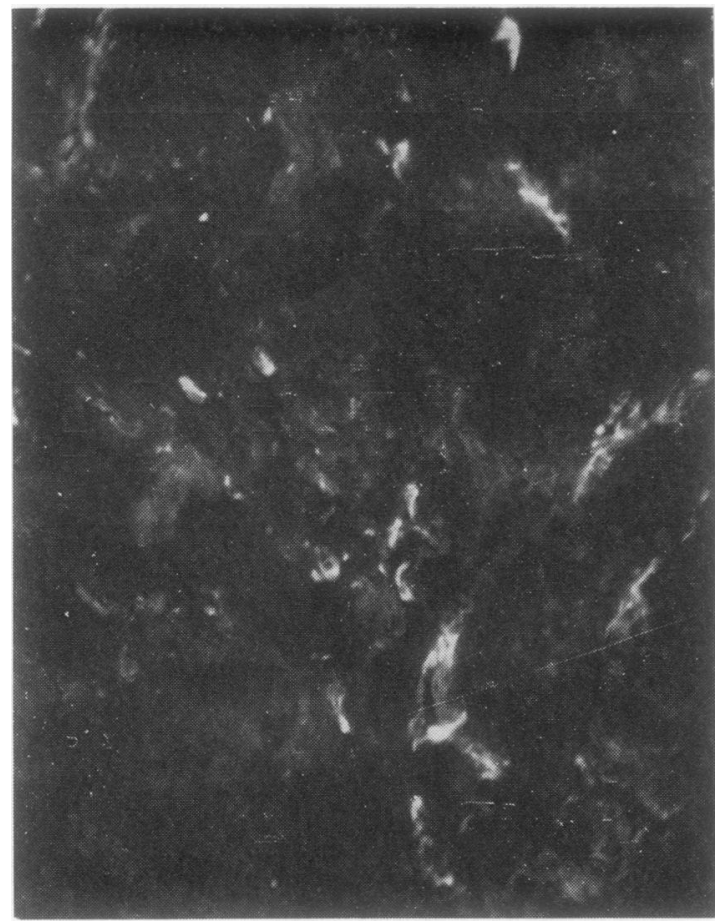

Fig. 2A. Immunofluorescent staining of synovium revealing IgM deposition around synovial vessels $(\times 80)$.

Table 4 Rheumatoid arthritis: immunofuorescent findings in 9 patients

\begin{tabular}{lccccccc}
\hline Location & $I g M$ & $I g G$ & $I g A$ & $I g E$ & $C 3$ & $C 4$ & $\begin{array}{l}\text { Fibrin/ } \\
\text { fibrinogen }\end{array}$ \\
\hline Vessels & 2 & 1 & 1 & 0 & 2 & 0 & 1 \\
Interstitial tissue & 6 & 4 & 2 & 0 & 3 & 0 & 6 \\
Lining cells & 2 & 1 & 2 & 1 & 0 & 0 & 0 \\
Infiltrating cells & 6 & 5 & 1 & 1 & 0 & 0 & 0 \\
\hline
\end{tabular}

Table 5 Juvenile rheumatoid arthritis: immunofuorescent findings in 5 patients

\begin{tabular}{lcccccccc}
\hline Location & IgM & IgG & IgA & IgE & C3 & C4 & $\begin{array}{c}\text { Fibrin/ } \\
\text { fibrinogen }\end{array}$ \\
\hline Vessels & 0 & 0 & 0 & 0 & 1 & 0 & 0 \\
Interstitial tissue & 1 & 0 & 0 & 0 & 0 & 0 & 3 \\
Lining cells & 0 & 0 & 0 & 0 & 0 & 0 & 0 \\
Infiltrating cells & 0 & 1 & 1 & 1 & 0 & 0 & 0 \\
\hline
\end{tabular}

only an isolated case showing a smooth linear pattern. The intensity of the staining was greatest for C3 and ranged from 1 to $3+$. Figs 2 and 3 illustrate the typical staining around synovial vessels with IgM and C3, respectively.

Results of immunofluorescent staining of synovium from control patients are shown in Tables 4 and 5. One of 6 patients with osteoarthritis had IgE deposition in the interstitial tissue. The others were negative. The 9 patients with rheumatoid arthritis

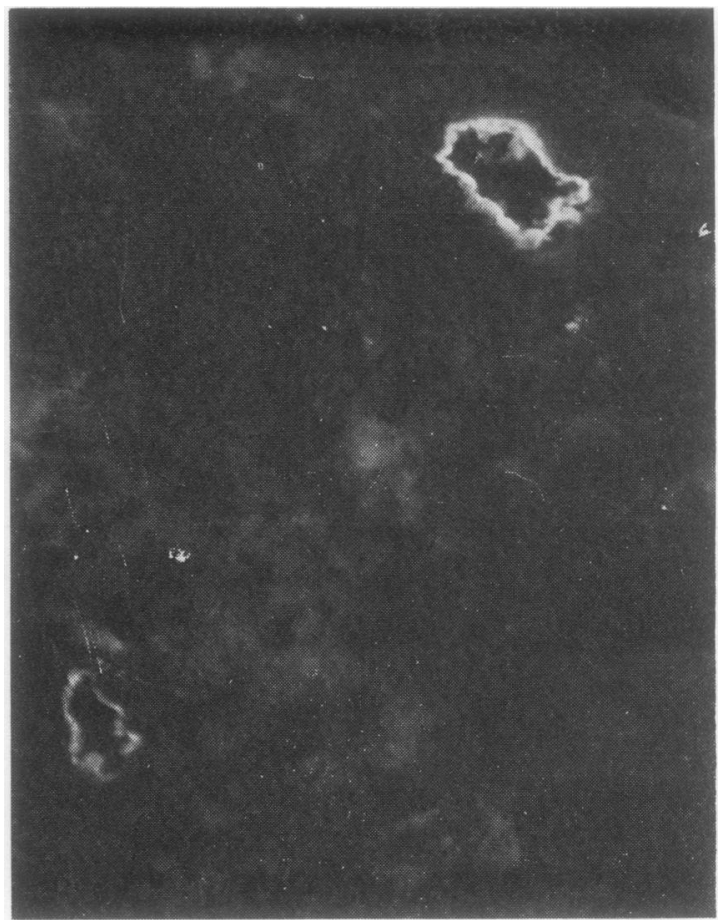

Fig. 2B. Immunofluorescent staining of synovium revealing IgM deposition around synovial vessels $(\times 200)$.

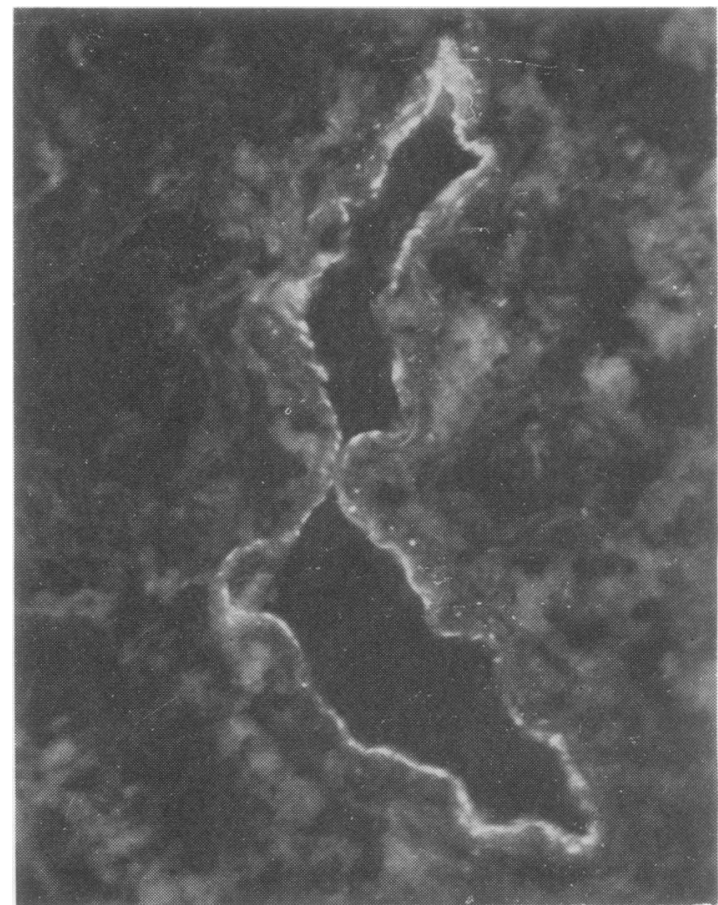

Fig. 3 Immunofluorescent staining of synovium

revealing $C 3$ deposition around a large vessel $(\times 200)$. 
showed immunoprotein staining, primarily with $\mathrm{IgM}, \mathrm{IgG}$, and $\mathrm{C} 3$, scattered in perivascular areas, interstitial tissue and lining, and infiltrating cells. In the 5 JRA patients 1 synovium stained with IgM in the interstitial tissue and 1 with $\operatorname{IgG}, \operatorname{IgA}$, and $\operatorname{IgE}$ in the infiltrating cells; $\mathrm{C} 3$ deposition was found in 1 case perivascularly.

\section{Discussion}

Although the aetiology of RS remains obscure, several mechanisms are probably involved in its pathogenesis. A relationship to infection is suggested by the nature of onset of the disease following sexual contact or dysentary. ${ }^{5-7}$ Genetic factors are probably important in the pathogenesis, since the majority of patients are HLA B27 positive. ${ }^{1}$ Reports of an increased occurrence of RS in some families also support this concept. $^{89}$ Another possible mechanism in the pathogenesis of RS is immunological.

Others have looked for immune deposits in the synovium of patients with RS. In 1968 Brandt et al. ${ }^{3}$ reported their findings in 2 patients with RS with synovitis of 2 days' and 3 months' duration. Both IgG and IgM were found in the interstitial tissue and in the cytoplasm of infiltrating cells, with IgG being more prominent. C3 was not found, and vessels were uninvolved. In 1969 Kinsella et al. ${ }^{10}$ were unable to find IgG and B1C component of complement in a synovial cell suspension of 1 patient with RS. More recently Yates et al. ${ }^{4}$ reported on synovial biopsies in 11 patients with RS. All had acute inflammation in the synovial tissue. B1C was seen in the synovial interstitial tissue in 7 patients and within infiltrating lymphocytes in 3 . IgG, IgA, and to a lesser extent IgM, were found interstitially in 5 cases and intracellularly in 6. Intracellular IgG and $\operatorname{IgA}$ were most conspicuous in the 3 cases where B1C was also found. In 2 cases complexes of IgG-B1C were identified. They also found a depressed synovial fluid complement level in 4 cases. Their results suggested complement activation in RS, thus lending support to the role of immunologic mechanisms.

Synovial biopsies in our patients with RS showed a fairly consistent pattern of immunoprotein deposition. Eleven of 12 synovia had deposits of IgM and C3; these were found predominantly in vessel walls and to a less extent in the interstitial tissue. This pattern was not seen in any of the control groups of biopsies from patients with OA, RA, or JRA. Fibrin/fibrinogen was regularly found in conjunction with IgM and C3; this was thought to represent a nonspecific phenomenon or possibly a manifestation of the interrelationship known to exist between clotting or fibrinolytic systems with inflammtory mechanisms.

The reason for the discrepancies in the type of immunoprotein deposition between our patients and those reported previously is unclear. Differences in technique cannot be excluded.

It is of interest that IgM (and not IgG) was found in the synovia of our patients. The reason for this is not known. In many conditions IgM antibodies are the primary immunoglobulins present after injury, especially in the early stages of an immune response. If more time elapsed, enabling the synovitis to become chronic, repeat synovial biopsies might possibly reveal a change from IgM to IgG deposition. However, this did not occur in the 5 synovia that were examined 4 or more weeks after the onset of arthritis.

While genetic factors and infection may be important, the finding of immunoproteins in the synovium of patients with RS suggests that immunological mechanisms are involved in the pathogenesis of this disease. An antigenic challenge from microbial agents or their by-products in a genetically susceptible host might cause an aberrant immune response which clinically manifests itself as RS. Alternatively, it is possible that some other unknown factor may directly damage synovial tissue with immunoglobulins and complement deposited secondarily. Clarification of the mechanisms responsible for our findings might lead to a better understanding of the pathogenesis of Reiter's syndrome.

\section{References}

1 Brewerton D A, Nicholls A, Oates J K, et al. Reiter's disease and HL-A27. Lancet 1973; ii: 996-8.

2 Morris R, Metzger A L, Bluestone R, et al. HLA-W27A clue to the diagnosis and pathogenesis of Reiter's syndrome. $N$ Engl J Med 1974; 290: 554-6.

3 Brandt K D, Cathcart E S, Cohen A S. Studies of immune deposits in synovial membranes and corresponding synovial fluids. J Lad Clin Med 72: 631-647, 1968.

4 Yates D B, Maini R N, Scott J T, et al. Complement activation in Reiter's syndrome. Ann Rheum Dis 1975; 34: 468.

5 Weinberger H W, Ropes M W, Kulka J P, et al. Reiter's syndrome, clinical and pathological observations. Medicine 1962; 41 : 35-86.

6 Paronen I. Reiter's disease-a study of 344 cases observed in Finland. Acta Med Scand 1948; 131 (suppl 212): 1-114.

7 Noer H R. An 'experimental' epidemic of Reiter's syndrome. JAMA 1966; 197: 117-22.

8 Kousa M, Lassus A, Karvonon J, et al. Family study of Reiter's disease and HLA-B27 distribution. J Rheumatol 1977; 4: 95-102.

9 Hochberg M C, Bias W B, Arnett F C. Family studies in HLA-B27 associated arthritis. Medicine 1978; 57: 46375.

10 Kinsella T D, Baum J, Ziff M. Immunofluorescent demonstration of IgG-B1C complex in synovial lining cells of rheumatoid synovial membrane. Clin Exp Immunol 1969 ; 4: 265-71. 